Cite this: J. Mater. Chem. A, 2014, 2, 3047

Received 28th October 2013 Accepted 11th January 2014

DOI: 10.1039/c3ta14383j

www.rsc.org/MaterialsA

\section{Development of $\mathrm{CaMn}_{1-x} \mathrm{Ru}_{x} \mathrm{O}_{3-y}(x=0$ and 0.15) oxygen reduction catalysts for use in low temperature electrochemical devices containing alkaline electrolytes: ex situ testing using the rotating ring-disk electrode voltammetry method}

\begin{abstract}
Cathryn A. Hancock, ${ }^{\text {*a }}$ Ai Lien Ong, ${ }^{\text {a }}$ Peter R. Slater ${ }^{b}$ and John R. Varcoe ${ }^{a}$
Various inorganic solid state catalysts are of interest for use as cathode catalysts in low temperature alkaline fuel cells including alkaline polymer electrolyte fuel cells. This ex situ study compares the oxygen reduction reaction in aqueous $\mathrm{KOH}\left(1 \mathrm{~mol} \mathrm{dm}{ }^{-3}\right)$ electrolyte on solid state and sol-gel synthesised $\mathrm{CaMn}_{1-x} \mathrm{Ru}_{x} \mathrm{O}_{3}$ $(x=0$ and 0.15 ) catalysts along with fuel-cell-grade Pt-based benchmark catalysts. The inclusion of Ru (e.g. in the $\mathrm{CaMn}_{0.85} \mathrm{Ru}_{0.15} \mathrm{O}_{3}$ examples) led to enhanced electronic conductivities compared to the $\mathrm{Ru}$ free exemplars. Rotating ring disk electrode hydrodynamic voltammetry was successfully used to determine the electron transfer numbers and hydrogen peroxide production yield for each catalyst. The electron transfer numbers of a number of the catalysts promisingly approach $n=4$ (the same as for the platinum benchmarks). However, the on-set potentials of the $\mathrm{CaMn}_{1-x} \mathrm{Ru}_{x} \mathrm{O}_{3}(x=0$ and 0.15$)$ catalysts were less than that of the Pt-based benchmarks and they also degraded in the alkaline conditions used (with a further decrease in onset potentials on degradation): the results from the study lead to the hypothesis that the degradation is related to the electrochemically generated peroxide.
\end{abstract}

\section{Introduction}

There are many problems with current energy production techniques, the most pressing being dwindling fossil fuel supplies in combination with an increase in global population and its increasing energy demands. ${ }^{1}$ Since the early 2000 's, shale gas has developed into a key oil and gas industry growth sector with resources being thought available for another 100+ years. However, this simply postpones the problem of diminishing fuel sources. ${ }^{2}$ In addition, the burning of fossil-derived fuels is inefficient and releases anthropogenic greenhouse gases into the atmosphere leading to undesirable climate change.

Fuel cells represent an excellent alternate energy conversion technology when compared to the burning of fossil fuels in internal combustion engines. There are many different types of fuel cell, that work under different conditions, which are being developed for various applications. Solid oxide fuel cells (SOFC) are generally used in high temperature applications such as generators for large scale power production. ${ }^{3}$ In contrast to SOFCs, polymer electrolyte fuel cells are mainly being developed for low temperature mobile and portable applications. ${ }^{4}$ This includes the recently advocated alkaline polymer

${ }^{a}$ Department of Chemistry, University of Surrey, Guildford, UK. E-mail: c.a.hancock@ surrey.ac.uk; Tel: +44 (0)1483 686838

${ }^{b}$ School of Chemistry, University of Birmingham, Edgbaston, Birmingham, UK electrolyte fuel cells (APEFC) that contain alkaline anionexchange membranes (AAEMs); this study is about this technology.

There are a number of issues that need to be investigated and problems to be solved, before such fuel cells become more widely used. This paper is focused on alternative cathode catalysts. Platinum-based catalysts are traditionally used (especially in proton-exchange membrane fuel cells) due to their high catalytic performances and relatively low over-potentials: ${ }^{5}$ the problem is the high cost and low abundance of such precious metals. There have been numerous studies that have focused on lowering the cost of these Pt-based catalysts. ${ }^{6,7}$ A common approach is to support the Pt metal on high surface area substrates, such as carbon, to lower the Pt-loading (this approach has been particularly successful at the anode). This approach is often in combination with the alloying of the Pt with cheaper elements such as Co. These Pt-alloy catalysts are, however, generally still expensive and can additionally exhibit reduced durabilities (leaching out of the non-noble metal component). As such, they do not represent the most ideal solution.

A different class of materials that has shown promise when used as catalysts in fuel cells are those based on low cost perovskite materials. These materials can have high ionic and electronic conductivities, and initial studies have shown promising oxygen reduction reaction (ORR) activities with a number of examples., ${ }^{5-12}$ A feature of perovskites that is 
attractive to researchers is the ability to incorporate a wide variety of cations (differing species and doping levels) that allows for a wide range of doping possibilities. Most research on using perovskites in fuel cells has focussed on the high temperature solid oxide systems: a considerable amount of research has involved the $\mathrm{La}_{1-x} \mathrm{Sr}_{x} \mathrm{MO}_{3}(\mathrm{M}=\mathrm{Mn}, \mathrm{Fe}$ and Co) system, which has the required ionic and electronic conductivities., ${ }^{\mathbf{9 1 0}, 12-19}$ Considering the success of using perovskite materials in high temperature fuel cells, research is now moving towards the lower temperature systems. A number of catalysts have shown promise for use as ORR catalysts at lower temperatures including $\mathrm{Pr}_{0.6} \mathrm{Ca}_{0.4} \mathrm{MnO}_{3}$ (ref. 20) and $\mathrm{Ca}_{0.9} \mathrm{La}_{0.1} \mathrm{MnO}_{3}{ }^{21}$ this study will focus on the $\mathrm{CaMnO}_{3}$ end member (to the latter) and will investigate the effect of a small amount of $\mathrm{Ru}$ doping. Standard Pt- and C-based electrodes and catalysts will be used as benchmarks.

\section{Methodology}

\section{Synthesis and structural analysis}

The synthesis of $\mathrm{CaMn}_{1-x} \mathrm{Ru}_{x} \mathrm{O}_{3-y}(x=0$ and 0.15$)$ was performed via two different methods: (1) solid state synthesis and (2) the sol-gel combustion method. These two contrasting techniques were both used to synthesise the catalysts in order to determine the method that would produce catalysts with the smallest particle size (with higher specific surface areas that are beneficial to application in fuel cells). Table 1 summarises the conditions used for all samples prepared. The following examples were the procedures used to synthesis the $x=0.15$ catalysts:

For a solid state method, high purity $\mathrm{CaCO}_{3}(2.00 \mathrm{~g}, 0.0200$ mol, 99\%, Fisher), $\mathrm{MnO}_{2}$ (1.48 g, $0.0170 \mathrm{~mol}$, 99\%, Sigma), and $\mathrm{RuO}_{2}$ (0.399 g, $0.00300 \mathrm{~mol}, 99.9 \%$, Sigma) were intimately ground and heated to $1100{ }^{\circ} \mathrm{C}$ for $12 \mathrm{~h}$ and then reground and reheated at $1300{ }^{\circ} \mathrm{C}$ for a further $12 \mathrm{~h}$.

For the sol-gel combustion method, high purity $\mathrm{Ca}(\mathrm{N}-$ $\left.\mathrm{O}_{3}\right)_{2} 4 \mathrm{H}_{2} \mathrm{O}(2.000 \mathrm{~g}, 0.008470 \mathrm{~mol}, 99 \%$, Sigma $), \mathrm{Mn}\left(\mathrm{NO}_{3}\right)_{2}(1.288$ g, $0.007198 \mathrm{~mol}, 99.98 \%$, Alfa Aesar), and $\mathrm{RuO}_{2}$ (0.169 g, 0.00127 mol, 99.9\%, Sigma) were dissolved in deionised water $\left(20 \mathrm{~cm}^{3}\right.$, resistivity $=18.2 \mathrm{M} \Omega \mathrm{cm}$ ) with stirring. High purity ethylenediaminetetraacetic acid (EDTA, $4.949 \mathrm{~g}, 0.01693 \mathrm{~mol}, 99 \%$, Sigma) and citric acid (3.254 g, $0.01693 \mathrm{~mol}, 99.8 \%$, Fisher) were added to the solution, which was then heated until the material formed a gel (typically $4 \mathrm{~h}$ ); the gel was then heated at $350{ }^{\circ} \mathrm{C}$ for $3 \mathrm{~h}$. The resulting powder was then ground and reheated twice, first at $600{ }^{\circ} \mathrm{C}$ for $12 \mathrm{~h}$ and then finally at $800{ }^{\circ} \mathrm{C}$ for $12 \mathrm{~h}$.

Powder X-ray diffraction (PANalytical Xpert Pro) was used to characterise the final catalysts $(\lambda=1.5406 \AA)$. This involved the determination of the phase purity, the structure of the material, and an estimation of the particle size; the latter was calculated using the Scherrer equation. ${ }^{22}$ Lattice parameters were calculated using the software Unit Cell (last updated 1998, Holland and Redfern).

\section{Electronic conductivity measurements}

The samples were first pressed into pellets and sintered at $1350{ }^{\circ} \mathrm{C}$. Four Pt electrodes were then attached to the pellet using Pt paste and heated to $1000{ }^{\circ} \mathrm{C}$ to ensure bonding to the sample. The temperature of the assembly was then decreased to $350{ }^{\circ} \mathrm{C}$ for $12 \mathrm{~h}$ to ensure full oxygenation. Conductivities $\left(\sigma / \mathrm{S} \mathrm{cm}^{-1}\right)$ of the samples were then measured at room temperature to $750{ }^{\circ} \mathrm{C}$ with $50{ }^{\circ} \mathrm{C}$ steps using the 4-probe d.c. $\operatorname{method}^{23}$ and calculated using eqn (1):

$$
\sigma=\frac{l}{A} \times \frac{I}{V}
$$

where $l=$ length between the wires $(\mathrm{cm}), A=$ cross sectional area of the pellet $\left(\mathrm{cm}^{2}\right), I=$ current $(\mathrm{A})$, and $V=$ voltage $(\mathrm{V})$.

\section{Catalyst ink preparation}

The catalyst to be electrochemically tested was first ground into a fine powder by ballmilling at $350 \mathrm{rpm}$ for $2 \mathrm{~h}$ in propanol (Fritsch Pulveriseette 7 Planetary Ballmill). Samples $(18.5 \mathrm{mg})$ were then suspended in propan-2-ol $\left(6.00 \mathrm{~cm}^{3}\right)$ containing Nafion 117 dispersion $\left(0.10 \mathrm{~cm}^{3}\right.$ of supplied dispersion, which is a $5 \%$ dispersion in lower aliphatic alcohols, Alfa Aesar). The resulting ink was shaken (by hand) before a $5 \mathrm{~mm}^{3}$ sample was taken and dropped onto the surface of a dry rotating Pt-ring glassy-carbon(GC)-disk electrode (Ametek, UK, disk area $=0.2475 \mathrm{~cm}^{2}$, ring inner diameter $\varnothing=0.625 \mathrm{~cm}$, ring outer $\varnothing=0.792 \mathrm{~cm}$ ) that had been cleaned as described below. The ink was allowed to dry and then the dropping procedure was repeated a further 3 times. The following catalysts were used for benchmarking: Vulcan $\mathrm{XC}-72 \mathrm{R}$ carbon powder (Pt-free benchmark), Pt/C (20\% m/m Pt, HiSPEC 3000, Alfa Aesar) and Pt black (HISPEC 1000, Alfa Aesar).

\section{Electrochemical procedure}

All electrochemical experiments with the rotating ring-disk electrodes (RRDE) were conducted using an IviumStat bipotentiostat (supplied by Alvatek, UK). This instrument also contained an internal impedance analyser. The instrument was controlled using IviumSoft software (version 1.831). The RRDEs rotation rates were controlled using a Pine rotator (supplied by Ametek). Polished, cleaned, and catalyst-ink-free Pt-ring Pt(polycrystalline)-disk (Ametek, UK, disk area $=0.1642 \mathrm{~cm}^{2}$, ring inner $\varnothing=0.493 \mathrm{~cm}$, ring outer $\varnothing=0.538 \mathrm{~cm}$ ) and Pt-ring glassy-carbon(GC)-disk RRDEs were used in control experiments.

Table 1 An outline of experimental procedures used for catalyst synthesis

\begin{tabular}{llll}
\hline Method & Initial process & $1^{\text {st }}$ heating step & Additional heating steps \\
\hline $\begin{array}{lll}\text { Sol-gel } \\
\text { Solid state }\end{array}$ & Dissolve and heat nitrates into a gel & $350{ }^{\circ} \mathrm{C}$ for $3 \mathrm{~h}$ & Grind and heat at $600{ }^{\circ} \mathrm{C}$ and $800{ }^{\circ} \mathrm{C}$ for $12 \mathrm{~h}$ \\
Grind oxide materials thoroughly & $1100{ }^{\circ} \mathrm{C}$ for $12 \mathrm{~h}$ & Grind $1300{ }^{\circ} \mathrm{C}$ for $12 \mathrm{~h}$
\end{tabular}


The RRDEs were polished by gently moving in a figure of eight pattern on a Rayon Microcloth disk (Buehler) coated with an alumina slurry (particle size $<0.05 \mu \mathrm{m}$ ) and then thoroughly rinsed with distilled water. The collection efficiency $(N)$ of each RRDE was determined by submerging in a solution of potassium ferricyanide $\left(\mathrm{K}_{3} \mathrm{Fe}(\mathrm{CN})_{6}, 10 \mathrm{mmol} \mathrm{dm}^{-3}\right)$ in aqueous $\mathrm{KCl}$ $\left(0.5 \mathrm{~mol} \mathrm{dm}^{-3}\right)$ and sweeping the disk potential between $0.5 \mathrm{~V}$ and $-0.5 \mathrm{~V}$ vs. $\mathrm{Ag} / \mathrm{AgCl}\left(3 \mathrm{~mol} \mathrm{dm}^{-3} \mathrm{NaCl}\right.$ internal solution) reference electrode at a sweep rate $=10 \mathrm{mV} \mathrm{s}^{-1}$; the ring potential was set at $0.6 \mathrm{~V}$ vs. $\mathrm{Ag} / \mathrm{AgCl}\left(3 \mathrm{~mol} \mathrm{dm}^{-3} \mathrm{NaCl}\right) . N$ was measured for each RRDE rotation rate used. The RRDEs were submerged in deionised water, when not in use.

The electrolyte used for the RRDE ORR studies was an aqueous solution of $\mathrm{KOH}$ ( $1 \mathrm{~mol} \mathrm{dm}^{-3}$, analytical grade, Fluka) and was used as supplied. The $\mathrm{KOH}$ electrolyte $\left(90 \mathrm{~cm}^{3}\right)$ was placed in a single compartment jacketed glass cell at $26^{\circ} \mathrm{C}$ and purged with $\mathrm{N}_{2}(99.999 \%$, BOC) for $3 \mathrm{~h}$ to ensure the complete removal of $\mathrm{CO}_{2}$ from the solution. After purging, the RRDE under study (polished as described above) was electrochemically cleaned by cycling between -1 and $+0.5 \mathrm{~V} v s$. $\mathrm{Ag} / \mathrm{AgCl}$ until reproducible voltammograms were obtained. Before the first ORR measurements, the aqueous solution was purged with $\mathrm{O}_{2}$ for $1 \mathrm{~h}$ to achieve full $\mathrm{O}_{2}$-saturation. The $\mathrm{O}_{2}$ purge pipe was then removed from the solution, but was left above the solution for the duration of the subsequent electrochemical measurement to ensure a blanket of oxygen above the electrolyte solution (without disturbing the electrolyte surface).

The RRDE under study (with/without addition of catalyst ink) was immersed into the $\mathrm{O}_{2}$ saturated aqueous solution along with a $\mathrm{Hg} / \mathrm{HgO}\left(1 \mathrm{~mol} \mathrm{dm}^{-3} \mathrm{KOH}\right.$ internal solution, Analytical grade, Fluka) reference electrode and a $\mathrm{Pt}$ wire counter electrode (surface area significantly larger than the area of the RRDE disk working electrode, length $=50 \mathrm{~cm}$ and $\varnothing=0.05 \mathrm{~cm})$. Immediately after immersion of the test RRDE into the solution, an impedance test (frequency range $10000-1000 \mathrm{~Hz}$, voltage perturbation rms amplitude $=10 \mathrm{mV}$ ) was recorded to determine the uncompensated $i R$-correction required. The RRDE test was performed with rotation rates in the range 200-1600 rpm. The reduction of $\mathrm{O}_{2}$ was carried out by sweeping the disk potential from +0.2 to $-1.0 \mathrm{~V} v s$. $\mathrm{Hg} / \mathrm{HgO}\left(1 \mathrm{~mol} \mathrm{dm}{ }^{-3} \mathrm{KOH}\right)$ at various scan rates (see figure captions); the ring potential was held at $+0.2 \mathrm{~V}$ vs. $\mathrm{Hg} / \mathrm{HgO}\left(1 \mathrm{~mol} \mathrm{dm}{ }^{-3} \mathrm{KOH}\right)$.

\section{Results and discussion}

\section{Powder XRD characterisation}

Fig. 1 shows the powder XRD profiles for the $\mathrm{CaMn}_{1-x} \mathrm{Ru}_{x} \mathrm{O}_{3}$ series synthesised by the two different methods. The catalyst materials are phase pure and the peaks correspond to an orthorhombic cell with a Pnma space group. The calculated lattice parameters are summarised in Table 2 . The cell parameters were not calculated for the sol-gel samples due to the broadness of the peaks, which makes reliable calculation of the small orthorhombic distortion difficult.

There is an increase in the unit cell volume on doping with $\mathrm{Ru}$ with both synthesis methods. This increase is due to the increase in size of $\mathrm{Ru}^{4+}$ (radius $r=76 \mathrm{pm}$, coordination number $\mathrm{CN}=6$ )

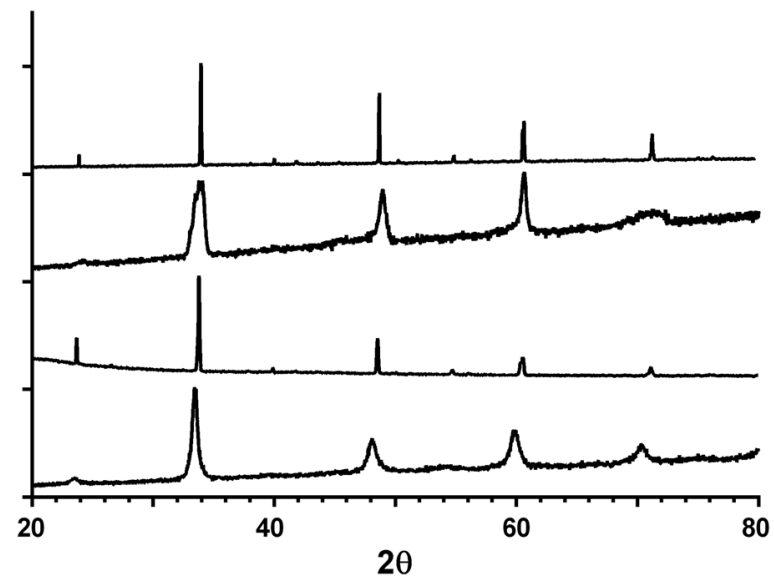

Fig. 1 Powder XRD profiles of the $\mathrm{CaMn}_{1-x} \mathrm{Ru}_{x} \mathrm{O}_{3}$ catalysts synthesised (from top to bottom): $\mathrm{CaMnO}_{3}$ (solid state method), $\mathrm{CaMnO}_{3}$ (sol-gel combustion method), $\mathrm{CaMn}_{0.85} \mathrm{Ru}_{0.15} \mathrm{O}_{3}$ (solid state method), $\mathrm{CaMn}_{0.85} \mathrm{Ru}_{0.15} \mathrm{O}_{3}$ (sol-gel combustion method).

compared to $\mathrm{Mn}^{4+}(r=67 \mathrm{pm}, \mathrm{CN}=6)$ along with the partial reduction of $\mathrm{Mn}^{4+}$ to $\mathrm{Mn}^{3+}(r=72 \mathrm{pm}, \mathrm{CN}=6)$. Smaller particle sizes are generally more beneficial for electrochemical purposes mainly due to increased specific (and electrochemically active) surface areas. The XRD data clearly shows that the sol-gel technique produced materials that yielded wider peaks compared to the materials produced using the solid state method. The data from the (llll), $\left.\begin{array}{lll}1 & 2 & 1\end{array}\right),\left(\begin{array}{lll}2 & 0 & 2\end{array}\right)$ and (l $\left.\begin{array}{lll}0 & 4\end{array}\right)$ peaks in Fig. 1 were used for Scherrer equation analysis. Even when considering the limitations of the equation, ${ }^{22}$ the data (Table 2) indicates that the sol-gel method produced catalysts with smaller particle sizes. Hence, the sol-gel samples were selected for use in the electrochemical RRDE tests detailed below.

\section{Electronic conductivity}

A good electrical conductivity is needed for a catalyst to have a high performance in an electrochemical device. A "standard" perovskite catalyst that is currently used in electrochemical devices is $\mathrm{La}_{1-x} \mathrm{Sr}_{x} \mathrm{MnO}_{3}$ (LSM) which typically exhibits conductivities in the range $7-284 \mathrm{mS} \mathrm{cm}^{-1}:^{5}$ this is comparable to the undoped $\mathrm{CaMnO}_{3}$ catalysts produced in this study. As seen in Fig. 2, the conductivity significantly increases on doping with $\mathrm{Ru}$ : this is a result of the partial reduction of the $\mathrm{Mn}^{4+} \rightarrow \mathrm{Mn}^{3+}$ yielding a mixed valency. In addition, the incorporation of $\mathrm{Ru}$ into the system doesn't hinder the electronic transport properties of the Mn-O network. Note that the conductivities could only be reliably measured for the solid state materials as the high sintering temperature required in the pellet making process enlarges the particle sizes of the sol-gel prepared samples.

\section{Electrochemical studies}

There are two reaction pathways that can occur for the ORR at the cathode of a fuel cell:

$$
\mathrm{O}_{2}+2 \mathrm{H}_{2} \mathrm{O}+4 \mathrm{e}^{-} \rightarrow 4 \mathrm{OH}^{-}\left(n=4 \mathrm{e}^{-} \text {ORR pathway }\right)
$$


Table 2 The cell parameters and estimated particle sizes (Scherrer analysis and its inherent assumptions) of the catalysts synthesised (calculated from powder XRD data).Cell parameters were not calculated for the sol-gel samples due to the broadness of the peaks, which makes reliable calculation of the small orthorhombic distortion difficult.

\begin{tabular}{lllllr}
\hline Composition & $a(\AA)$ & $b(\AA)$ & $c(\AA)$ & Cell volume $\left(\AA^{3}\right)$ & Estimated average particle size $(\mathrm{nm})$ \\
\hline $\mathrm{CaMnO}_{3}$ (solid state) & $5.2812(4)$ & $7.4620(4)$ & $5.2761(7)$ & $207.92(2)$ & 113 \\
$\mathrm{CaMnO}_{3}($ sol-gel) & - & - & - & - & 13 \\
$\mathrm{CaMn}_{0.85} \mathrm{Ru}_{0.15} \mathrm{O}_{3}$ (solid state) & $5.3116(4)$ & $7.4915(4)$ & $5.2892(7)$ & $210.46(2)$ & 67 \\
$\mathrm{CaMn}_{0.85} \mathrm{Ru}_{0.15} \mathrm{O}_{3}$ (sol-gel) & - & - & - & - & 14
\end{tabular}

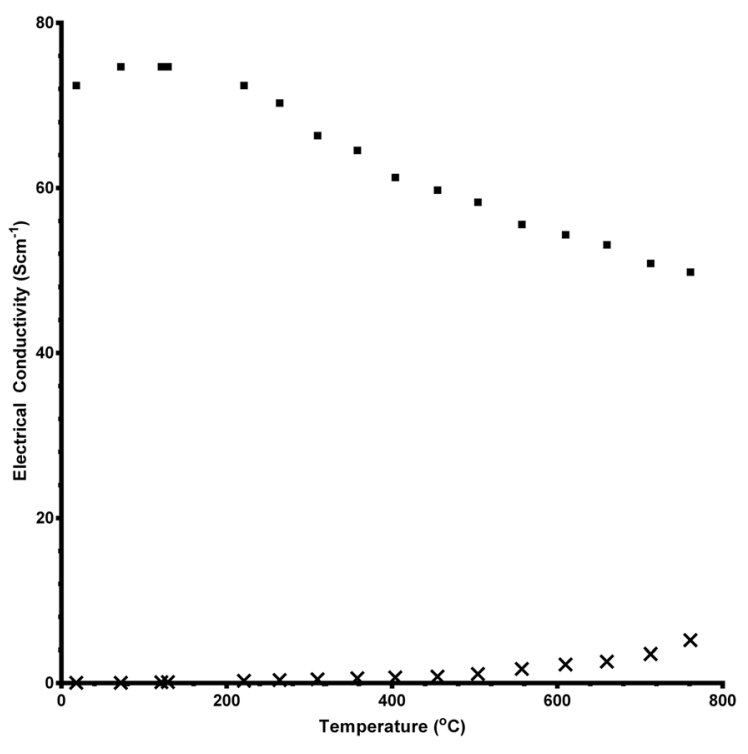

Fig. 2 Electronic conductivity data between room temperature and $750{ }^{\circ} \mathrm{C}$ for $\mathrm{CaMn}_{1-x} \mathrm{Ru}_{x} \mathrm{O}_{3}$ synthesised using the solid state method. ( $x$ $=0$ data $=$ crosses and $x=0.15$ data $=$ squares $)$.

$\mathrm{O}_{2}+\mathrm{H}_{2} \mathrm{O}+2 \mathrm{e}^{-} \rightarrow \mathrm{HO}_{2}^{-}+\mathrm{OH}^{-}\left(n=2 \mathrm{e}^{-}\right.$ORR pathway) $(3)$

The more efficient (desirable) reaction mechanism is the 4electron reduction which occurs on Pt catalysts (in acid and alkaline media) to produce water (eqn (2)). However there is a competing mechanism, the 2-electron process, which produces undesirable peroxide species (eqn (3)). Not only is this process electron inefficient (each $\mathrm{O}_{2}$ molecule only reacts with $2 \mathrm{e}^{-}$) but the generation of peroxide species (and potentially the very damaging $\mathrm{HO}^{\circ}$ and $\mathrm{HOO}^{\circ}$ radicals) can be detrimental to (lead to degradation of) the catalyst and other device components, especially polymeric components (including fully fluorinated types).

There are a couple of methods that can be used to determine the number of $\mathrm{e}^{-}$consumed $(n)$ in an ORR reaction. Both involve the use of rotating electrode hydrodynamic voltammetry. Method 1 involves a rotating disk electrode (RDE) and a potentiostat: the number of electrons transferred is calculated using Koutecky-Levich (K-L) analysis. This method involves less complex and less expensive equipment but is most suited only to simple catalysts, such as metallic Pt and Au: K-L analysis does not always give the correct $n$ value (as well as not being able to directly determine the amount of peroxide species produced) with more complex catalysts that contain transition metal centres that can undergo internal redox processes and that can cause interferences/uncertainties with the RDE disk areas due to the application of the catalyst layers (validated methods, that are required for determining the precise electrochemically active surface areas needed for further analyses [such as full Tafel plot analysis and determination of specific activities], may also not be available for more complex catalysts). Hence, Method 2 was selected for evaluating the catalysts produced in this study, which uses a rotating ring-disk electrode (RRDE) and a bipotentiostat (controls the potential of the disk and ring independently, whilst simultaneously recording the currents at the ring and disk): the currents recorded at both the ring and the disk are used to calculate peroxide yield. Note that K-L analysis can still be attempted when using RRDEs.

Before conducting experiments on the catalysts, to determine the amount of peroxide formed from the ORR, the collection efficiency $(N)$ of the ring electrode must first be calculated. There are two methods for achieving this: one is

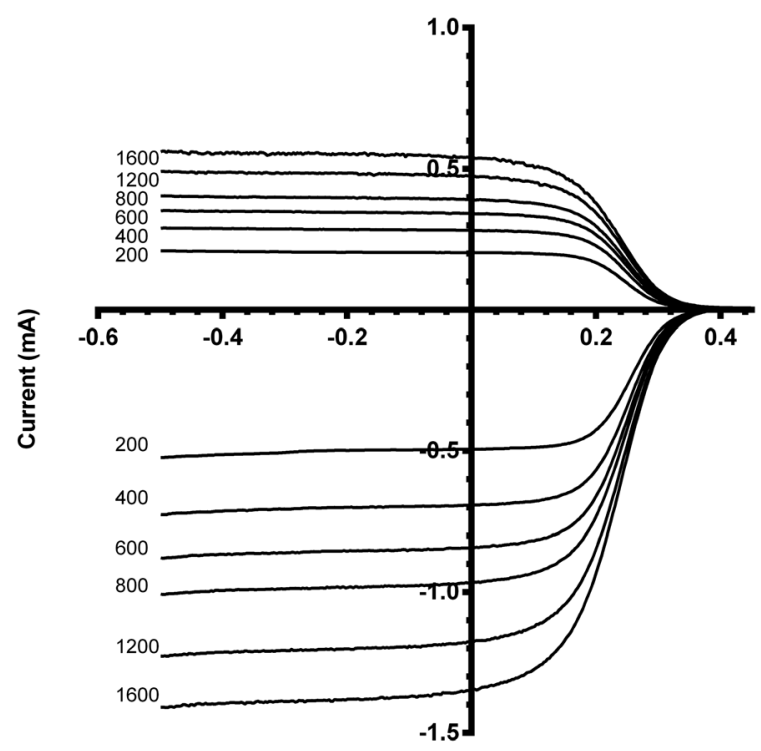

Potential (V) vs Ag/AgCl (3M NaCl)

Fig. 3 Exemplar Pt-ring GC-disk electrode RRDE hydrodynamic voltammograms for the reduction of $\mathrm{K}_{3} \mathrm{Fe}(\mathrm{CN})_{6}\left(10 \mathrm{mmol} \mathrm{dm}^{-3}\right)$ at the disk electrode in $\mathrm{N}_{2}$-purged aqueous $\mathrm{KCl}\left(0.5 \mathrm{~mol} \mathrm{dm}^{-3}\right)$. Scan rate $=10 \mathrm{mV}$ $\mathrm{s}^{-1}$ with rotation rates of $200,400,600,800,1200$ and $1600 \mathrm{rpm}$. 


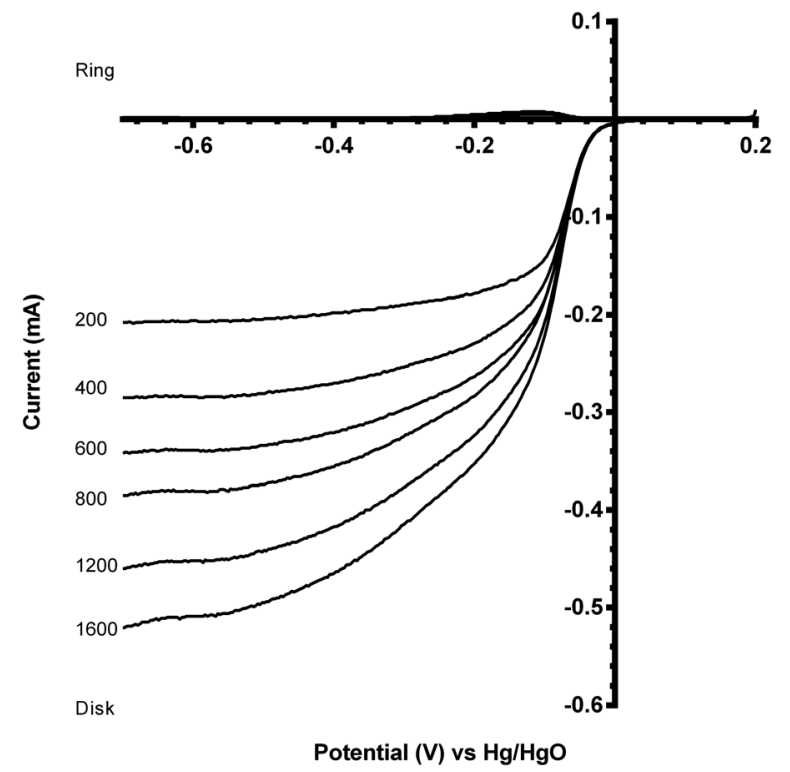

Fig. 4 Voltammograms for the oxygen reduction reaction (ORR) in $\mathrm{O}_{2}$-saturated aqueous $\mathrm{KOH}\left(1 \mathrm{~mol} \mathrm{dm}^{-3}\right)$ on a Pt-ring Pt(polycrystalline)-disk control RRDE. Scan rate $=5 \mathrm{mV} \mathrm{s}^{-1}$ with rotation rates of 200, 400,600,800, 1200 and $1600 \mathrm{rpm}$.

theoretical and the second is experimental. Generally the experimental method is preferred (and used in this study) as the theoretical method requires the precise dimensions of the electrode, which are generally unknown due to the machining process used and changes brought on from the polishing and cleaning regimen and the ink deposition process. To experimentally measure $N$, a well-known redox system, such as the ferrocyanide/ferricyanide system (a simple, single electron, and reversible couple), is used. When the voltage of the disk is swept to negative values (the ring is held at a constant potential), the ferricyanide is reduced at the disk to ferrocyanide, which is then swept to the ring where it is oxidised back into ferricyanide (eqn (4) and eqn (5)):

$$
\begin{aligned}
& \text { Reduction at disk: } \mathrm{Fe}(\mathrm{CN})_{6}{ }^{3-}+\mathrm{e}^{-} \rightarrow \mathrm{Fe}(\mathrm{CN})_{6}{ }^{4-} \\
& \text { Oxidation at ring: } \mathrm{Fe}(\mathrm{CN})_{6}{ }^{4-} \rightarrow \mathrm{Fe}(\mathrm{CN})_{6}{ }^{3-}+\mathrm{e}^{-}
\end{aligned}
$$

Not all of the ferrocyanide contacts with the ring: the ratio between the ring and disk limiting currents is the collection efficiency $N$ (Fig. 3 and eqn (6)):

$$
N=100 \% \times\left(-I_{\mathrm{R}} / I_{\mathrm{D}}\right)
$$

where $I_{\mathrm{R}}$ is the ring limiting current and $I_{\mathrm{D}}$ is the disk limiting currents. Two RRDEs were used in this study. The Pt-ring Pt-disk control RRDE had $N=24 \%$ while the Pt-ring glassycarbon(GC)-disk electrode (used for the study of the catalysts) had $N=41 \%$.

Benchmarking experiments were performed on a number of standard Pt catalysts deposited on the disk of a Pt-ring GC-disk RRDE. Control experiments involved measurements with a Ptring Pt(polycrystalline)-disk electrode to determine whether the experimental method produced the expected 4-electron ORR. Fig. 4 shows the ORR voltammograms for the Pt-ring Pt-disk control RRDE. Using this data, along with the prior measured collection efficiency, the percentage peroxide produced and the electron transfer $(n)$ number were calculated using eqn (7) and eqn (8): ${ }^{24}$

$$
\begin{gathered}
\% \text { peroxide }=\left(\frac{200 \times I_{\mathrm{R}}}{N}\right) /\left(I_{\mathrm{D}}+\frac{I_{\mathrm{R}}}{N}\right) \\
n=\frac{4 \times I_{\mathrm{D}}}{\left(I_{\mathrm{D}}+\frac{I_{\mathrm{R}}}{N}\right)}
\end{gathered}
$$

As seen in Fig. 4, the ring currents are very low, which indicate very little peroxide generation, with $n$ values approaching 4 (see Table 3). These values are expected with a polycrystalline Pt-disk electrode, which indicates that this

\begin{tabular}{|c|c|c|c|}
\hline Electrode & $\begin{array}{l}\% \text { peroxide, mean } \pm \\
\text { std dev. (sample size) }\end{array}$ & $\begin{array}{l}n, \text { mean } \pm \text { std } \\
\text { dev. (sample size) }\end{array}$ & $\begin{array}{l}\text { Onset potential } \\
\text { at }-0.05 \mathrm{~mA}\end{array}$ \\
\hline Pt-disk (Pt-ring Pt-disk RRDE) & $2.5 \pm 0.87(6)$ & $3.95 \pm 0.02(6)$ & $-0.05^{c}$ \\
\hline GC-disk (Pt-ring GC-disk RRDE) & $71.5 \pm 6.24(6)$ & $2.57 \pm 0.12(6)$ & $-0.271^{c}$ \\
\hline Vulcan XC-72R carbon black ${ }^{a}$ & $70.7 \pm 5.92(6)$ & $2.59 \pm 0.12(6)$ & $-0.139^{c}$ \\
\hline $\mathrm{Pt} / \mathrm{C}(20 \% \mathrm{~m} / \mathrm{m} \mathrm{Pt})^{a}$ & $21.1 \pm 1.26(6)$ & $3.58 \pm 0.03(6)$ & $-0.007^{c}$ \\
\hline Platinum black ${ }^{a}$ & $22.9 \pm 3.13(6)$ & $3.54 \pm 0.06(6)$ & $0.032^{c}$ \\
\hline $\mathrm{CaMnO}_{3}{ }^{a, b}$ & $41.1 \pm 3.19(6)$ & $3.18 \pm 0.06(6)$ & $-0.256^{c}$ \\
\hline $\mathrm{CaMn}_{0.85} \mathrm{Ru}_{0.15} \mathrm{O}_{3}{ }^{a, b}$ & $47.8 \pm 3.03(6)$ & $3.04 \pm 0.06(6)$ & $-0.235^{c}$ \\
\hline $\mathrm{CaMnO}_{3} /$ Vulcan XC-72R $\mathrm{R}^{a, b}$ & $36.7 \pm 3.04(6)$ & $3.27 \pm 0.06(6)$ & $-0.235^{c}$ \\
\hline $\mathrm{CaMn}_{0.85} \mathrm{Ru}_{0.15} \mathrm{O}_{3} /$ Vulcan XC-72R $\mathrm{R}^{a, b}$ & $41.1 \pm 2.44(6)$ & $3.18 \pm 0.05(6)$ & $-0.235^{c}$ \\
\hline $\mathrm{CaMnO}_{3}$ before degradation ${ }^{a}$ & $31.4^{c}$ & $3.37^{c}$ & $-0.232^{c}$ \\
\hline $\mathrm{CaMn}_{0.85} \mathrm{Ru}_{0.15} \mathrm{O}_{3}$ before degradation ${ }^{a}$ & $50.83^{c}$ & $2.98^{c}$ & $-0.202^{c}$ \\
\hline $\mathrm{CaMnO}_{3} /$ Vulcan XC-72R before degradation ${ }^{a}$ & $27.4^{c}$ & $3.45^{c}$ & $-0.091^{c}$ \\
\hline $\mathrm{CaMn}_{0.85} \mathrm{Ru}_{0.15} \mathrm{O}_{3} /$ Vulcan XC-72R before degradation ${ }^{a}$ & $36.9^{c}$ & $3.26^{c}$ & $-0.106^{c}$ \\
\hline
\end{tabular}
technique is valid.

Table 3 Data showing the peroxide production and electron transfer ( $n$ ) values for each electrode and catalyst studied. Data was collected when the currents had plateaued. An average was taken of all the rotation speeds except for the pre-degraded catalysts, where a single measurement was taken at $200 \mathrm{rpm}$. Onset potentials vs. $\mathrm{Hg} / \mathrm{HgO}\left(1 \mathrm{~mol} \mathrm{dm}{ }^{-3} \mathrm{KOH}\right)$ reference electrode were taken at $-0.05 \mathrm{~mA}$ at $200 \mathrm{rpm}$ for all catalysts.

${ }^{a}$ Catalyst ink deposited on the GC-disk of a Pt-ring GC-disk RRDE. ${ }^{b}$ Data for these catalysts after degradation. ${ }^{c}$ Data for $200 \mathrm{rpm}$ only. 


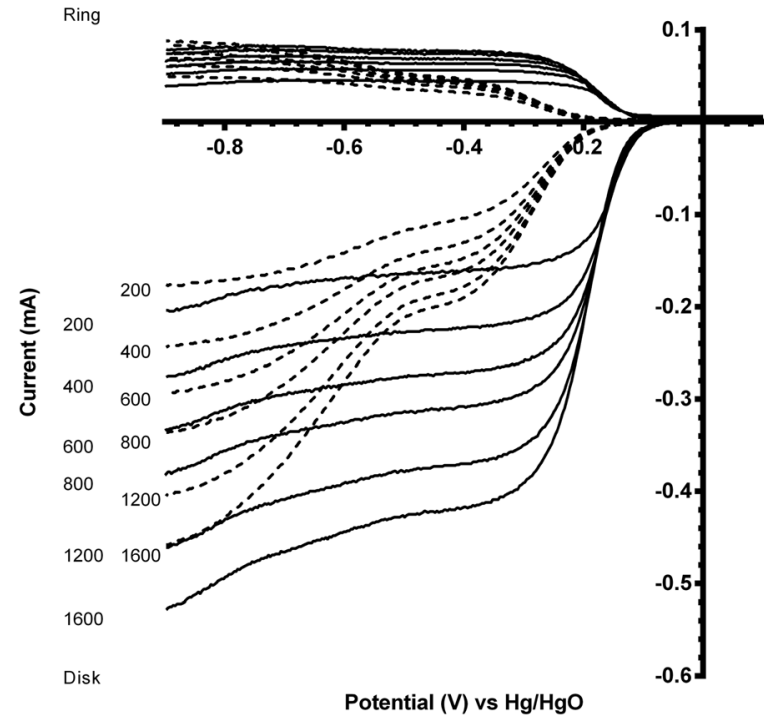

Fig. 5 Voltammograms for the ORR in $\mathrm{O}_{2}$-saturated aqueous $\mathrm{KOH}(1$ mol $\mathrm{dm}^{-3}$ ) for the Pt-ring GC-disk RRDE with (solid) and without (dashed) Vulcan XC-72R carbon black deposited on the GC-disk. Scan rate $=5 \mathrm{mV} \mathrm{s}^{-1}$ with rotation rates of 200,400,600,800, 1200 and $1600 \mathrm{rpm}$.

A comparison of the ORR polarisation curves for the control Pt-ring GC-disk RRDE (without added catalysts) and the Pt-ring GC-disk benchmark RRDE where the GC-disk was coated with a catalyst ink containing Vulcan XC-72R carbon black powder $(0.07 \mathrm{mg})$ are presented in Fig. 5 . The onset potentials increased to more positive values with the Vulcan. This improvement can be attributed to the higher specific surface area and the different surface functionalisation of the Vulcan, compared to the blank GC-disk, resulting in a higher number of active sites.

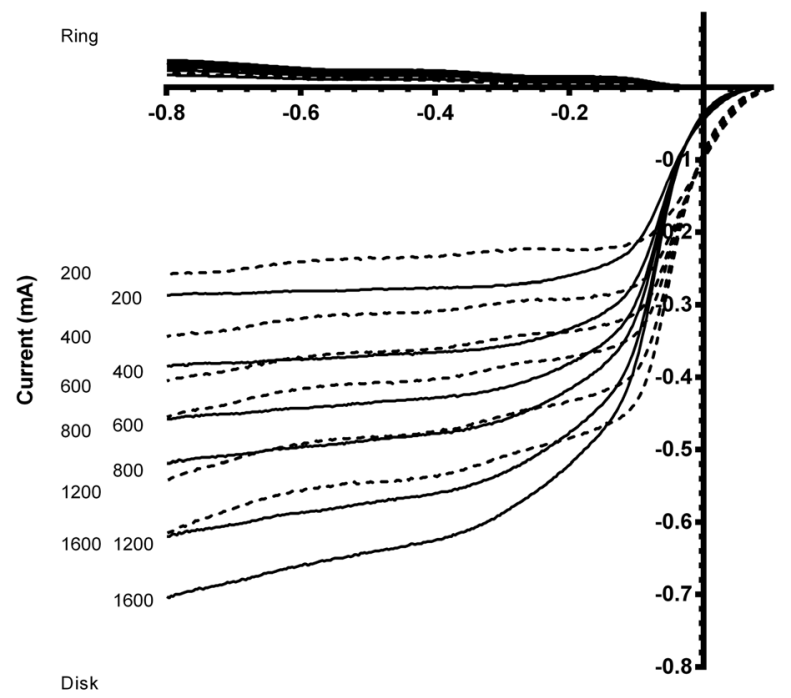

Potential (V) vs $\mathrm{Hg} / \mathrm{HgO}$

Fig. 6 Voltammograms for the ORR in $\mathrm{O}_{2}$-saturated aqueous $\mathrm{KOH}(1$ mol dm ${ }^{-3}$ ) for the Pt-ring GC-disk RRDE with Pt/C (solid) and Pt black (dashed) catalysts deposited on the GC-disk. Scan rate $=5 \mathrm{mV} \mathrm{s}^{-1}$ with rotation rates of $200,400,600,800,1200$ and $1600 \mathrm{rpm}$.

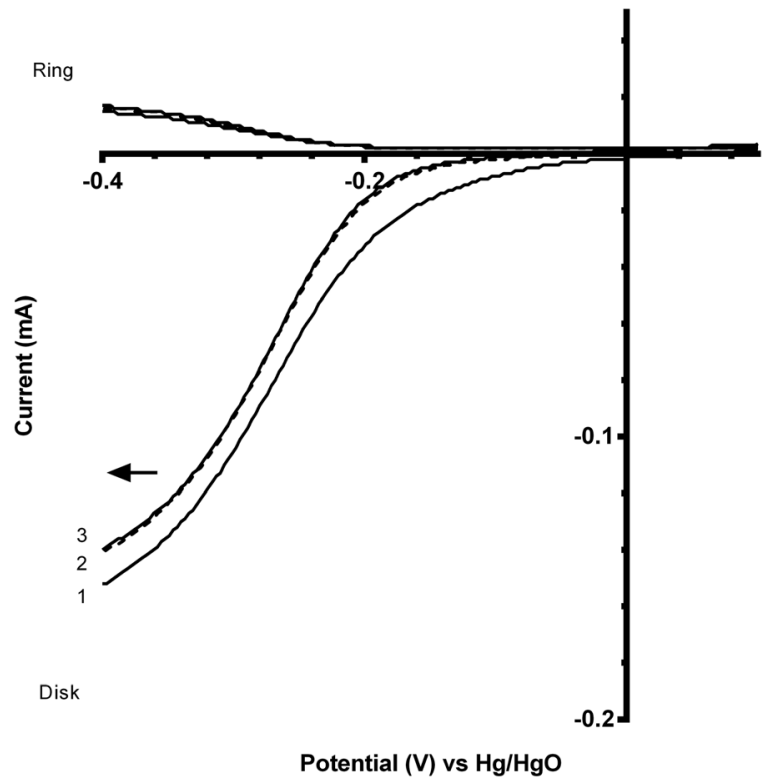

Fig. 7 Voltammograms (sequential scans in the direction of the arrow) for the ORR in $\mathrm{O}_{2}$-saturated aqueous $\mathrm{KOH}\left(1 \mathrm{~mol} \mathrm{dm}^{-3}\right)$ electrolyte with the $\mathrm{CaMnO}_{3}$ sol-gel catalyst. Scan rate $=20 \mathrm{mV} \mathrm{s}^{-1}$ and RRDE rotation rate $=200 \mathrm{rpm}$.

However, while the onset potential increased, the \% peroxide yield and $n$ value were the same (Table 3 ).

The two standard benchmark Pt catalysts studied were $\mathrm{Pt} / \mathrm{C}$ $(20 \% \mathrm{~m} / \mathrm{m} \mathrm{Pt}, 0.07 \mathrm{mg}$ catalyst on the electrode) and Pt black ( $0.07 \mathrm{mg}$ catalyst on the electrode). Fig. 6 shows that the Pt black has a more positive onset potential compared to the $\mathrm{Pt} / \mathrm{C}$, which was expected due to the increased amount of $\mathrm{Pt}$ in the pure $\mathrm{Pt}$ black (less interference due to the absence of carbon black support, which, as shown above, yields closer to $n=2 \mathrm{e}^{-}$ORR) and a particle size effect (larger Pt particle size for the Pt black). The $n$ values for both Pt benchmark catalysts were comparable (Table 3) at $n>3.5$ (there is still the GC disk causing an $n=2$ competitive reaction - only the Pt-ring Pt-disk electrode with no carbon in the electrode approaches $n=4$ as discussed above).

Fig. 7 and 8 shows the ORR voltammograms for the $\mathrm{CaMnO}_{3}$ and $\mathrm{CaMn}_{0.85} \mathrm{Ru}_{0.15} \mathrm{O}_{3}$ sol-gel catalysts after a number of sequential scans: this experiment was to probe the stability of the catalysts. Each scan was conducted at the same rotation and scan rate. There was a rapid decline in the onset potential (shifted to more negative potentials) with a final stabilisation after the $3^{\text {rd }}$ or $4^{\text {th }}$ sequential scan. The percentage of potential loss at $-0.1 \mathrm{~mA}$ for both catalysts were calculated using eqn (9): ${ }^{25}$

$$
\% E_{\mathrm{loss}}=100 \% \times \frac{E_{\mathrm{ini}}-E}{E_{\mathrm{ini}}}
$$

where $E_{\text {ini }}=$ onset potential in the first scan and $E=$ the onset potential of the $n^{\text {th }}$ scan being studied. The catalysts were observed to have $5-10 \%$ (Table 4 ) decreases in onset potential after even these low numbers of scans. This decrease is due to the catalysts being unstable in the presence of peroxide (produced in $n<4 \mathrm{ORR}$ ) and $\mathrm{KOH}$; this was confirmed by additional experiments involving the immersion of the samples in aqueous $\mathrm{KOH}$ and $\mathrm{H}_{2} \mathrm{O}_{2}$ solutions and subsequent XRD 


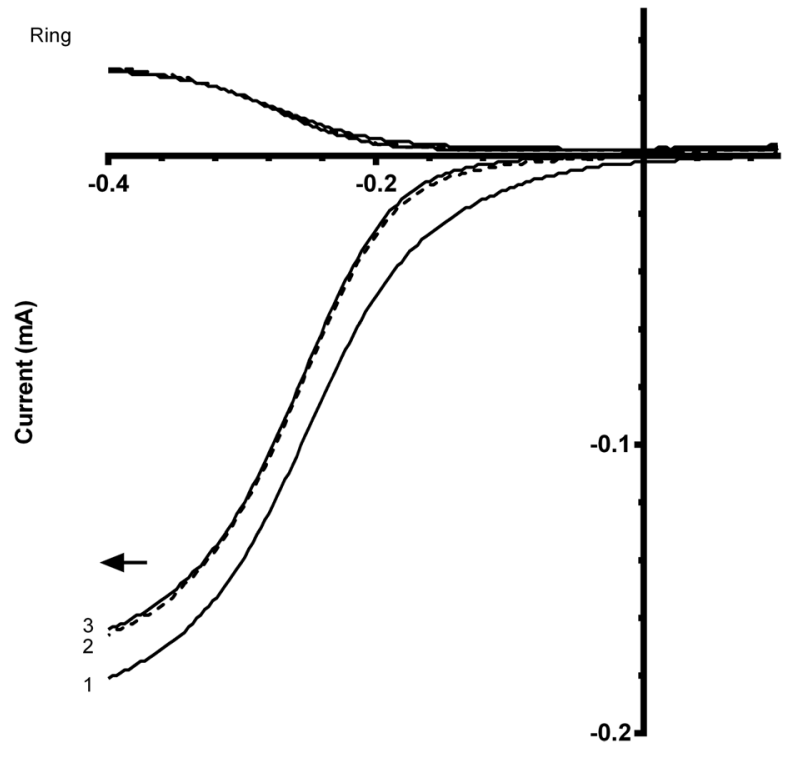

Disk

\section{Potential (V) vs $\mathrm{Hg} / \mathrm{HgO}$}

Fig. 8 Voltammograms (sequential scans in the direction of the arrow) for the ORR in $\mathrm{O}_{2}$-saturated aqueous $\mathrm{KOH}\left(1 \mathrm{~mol} \mathrm{dm}^{-3}\right)$ electrolyte with the $\mathrm{CaMn}_{0.85} \mathrm{Ru}_{0.15} \mathrm{O}_{3}$ sol-gel catalyst. Scan rate $=20 \mathrm{mV} \mathrm{s}^{-1}$ and $\mathrm{RRDE}$ rotation rate $=200 \mathrm{rpm}$.

Table 4 Data showing the onset potential loss (\% $E_{\text {loss }}$ - defined in eqn (9)) after each sequential cycle for the $\mathrm{CaMn}_{1-x} \mathrm{Ru}_{x} \mathrm{O}_{3}(x=0$ and 0.15 sol-gel synthesised) with and without the addition of Vulcan XC-72R into the catalyst ink. Test conditions as in Fig. 7.

\begin{tabular}{lllll}
\hline & \multicolumn{3}{c}{$\mathrm{CaMnO}_{3}+$} & $\begin{array}{l}\mathrm{CaMn}_{0.85} \mathrm{Ru}_{0.15} \mathrm{O}_{3}+ \\
\text { Cycle }\end{array}$ \\
\hline $\mathrm{CaMnO}_{3}$ & Vulcan & $\mathrm{CaMn}_{0.85} \mathrm{Ru}_{0.15} \mathrm{O}_{3}$ & Vulcan \\
1 & 0 & 0 & 0 & 0 \\
2 & 5 & 82 & 8 & 52 \\
3 & 5 & 101 & 8 & 63 \\
4 & - & 106 & - & 67 \\
5 & - & 108 & - & 67
\end{tabular}

analysis: an extra XRD peak was observed at $2 \theta=29.37^{\circ}$, which was provisionally allocated to $\mathrm{CaCO}_{3}(\mathrm{~s})$.

Before this catalyst degradation, the beginning-of-life onset potentials were superior to the GC-disk control but were inferior to that of the Vulcan XC-72R carbon black benchmark. Despite this poor onset potential performance measure, the \% peroxide yield were lower and the $n$ values were greatly improved (Table $3)$. The comparison between the Ru-doped and the undoped sol-gel catalysts were as expected (Fig. 9). The onset potential was more positive on doping with the small amount of the precious metal $\mathrm{Ru}$ (used in the past as a co-metal in Pt-alloy anode catalysts in low temperature direct methanol fuel cells and with fuel cells fuelled with reformed $\mathrm{H}_{2}$ that contained traces of $\mathrm{CO}$ ). In addition, the electrical conductivity of the Ru-doped catalyst is significantly increased compared to the undoped example: this will lead to less ohmic drops inside the catalyst layer.

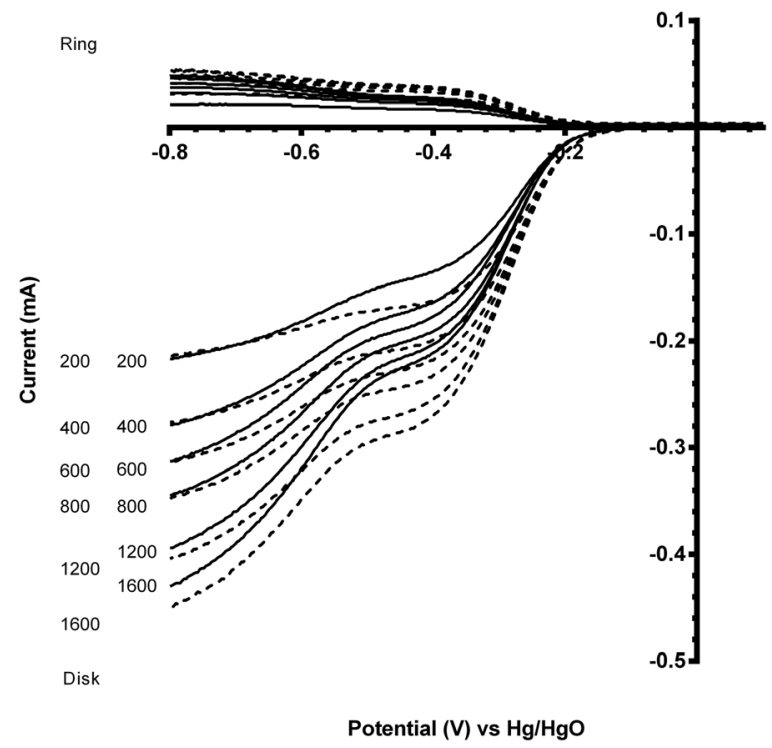

Fig. 9 Voltammograms for the ORR in $\mathrm{O}_{2}$-saturated aqueous $\mathrm{KOH}(1$ mol $\mathrm{dm}^{-3}$ ) electrolyte with the degraded $\mathrm{CaMn}_{1-x} \mathrm{Ru}_{x} \mathrm{O}_{3}[x=0$ (solid) and 0.15 (dashed)] sol-gel catalysts (studied after 3 voltammetric sweeps - refer to Fig. 7). Scan rate $=5 \mathrm{mV} \mathrm{s}^{-1}$ with rotation rates of 200, 400,600, 800, 1200 and $1600 \mathrm{rpm}$.

The perovskite catalysts were also tested with the addition of Vulcan XC-72R carbon powder (5:1 mass ratio of $\mathrm{CaMn}_{1-x}$ $\mathrm{Ru}_{x} \mathrm{O}_{3}$ : Vulcan) to see the effect of the addition of a more electronically conductive component. However, the addition of the carbon black component led to an enhanced (undesirable) loss of onset potential over several sequential potential sweeps, compared to the catalysts in the absence of carbon black (Fig. 10

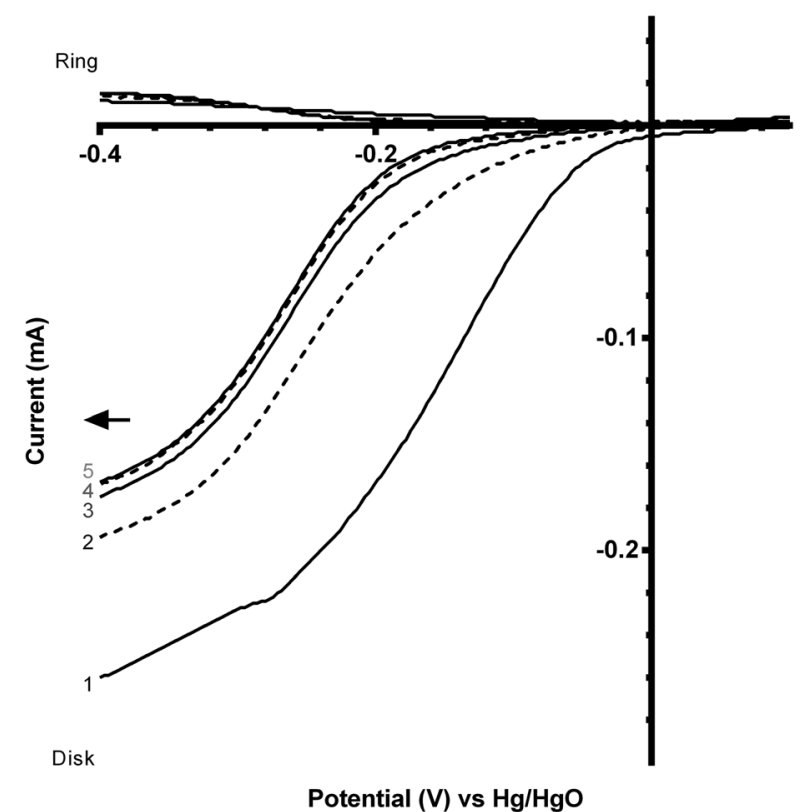

Fig. 10 Voltammograms (sequential scans in the direction of the arrow) for the ORR in $\mathrm{O}_{2}$-saturated aqueous $\mathrm{KOH}\left(1 \mathrm{~mol} \mathrm{dm}^{-3}\right)$ electrolyte with a catalyst containing $\mathrm{CaMnO}_{3}$ : Vulcan (5:1 mass ratio). Scan rate $=20 \mathrm{mV} \mathrm{s}^{-1}$ and $\mathrm{RRDE}$ rotation rate $=200 \mathrm{rpm}$. 


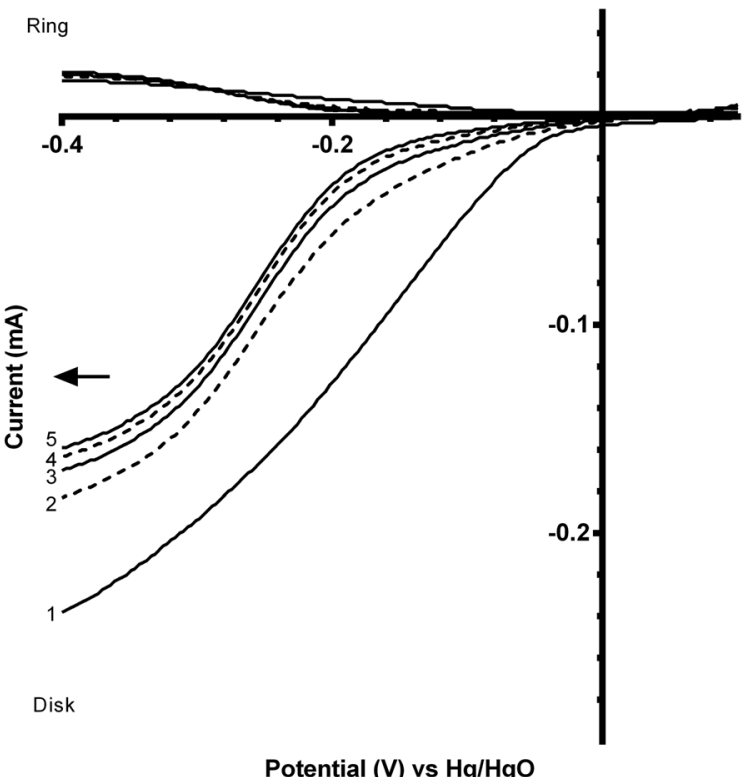

Fig. 11 Voltammograms (sequential scans in the direction of the arrow) for the ORR in $\mathrm{O}_{2}$-saturated aqueous $\mathrm{KOH}\left(1 \mathrm{~mol} \mathrm{dm}^{-3}\right)$ electrolyte with a catalyst containing $\mathrm{CaMn}_{0.85} \mathrm{Ru}_{0.15} \mathrm{O}_{3}$ : Vulcan $(5: 1$ mass ratio). Scan rate $=20 \mathrm{mV} \mathrm{s}^{-1}$ and RRDE rotation rate $=200 \mathrm{rpm}$.

and 11 and Table 4). From the data shown in Table 4 there is a significant decrease in the loss of onset potential when doped with $\mathrm{Ru}$. This is hypothesised to be due to the Ru stabilising the structure of the catalyst. As the ORR is predominantly $n=2 \mathrm{e}^{-}$ on Vulcan XC-72 (see Table 3), this result provides further corroboratory evidence that the presence of peroxide is a primary cause of this degradation in onset potentials over the first few voltammetry sweeps with these inorganic catalysts.

It would be highly desirable if these catalysts could be developed so that they are resistant to this peroxide-derived degradation: this is because of the observed and desirable increase in the onset potential (more positive) with the predegradation perovskite/carbon mixed catalyst compared to the

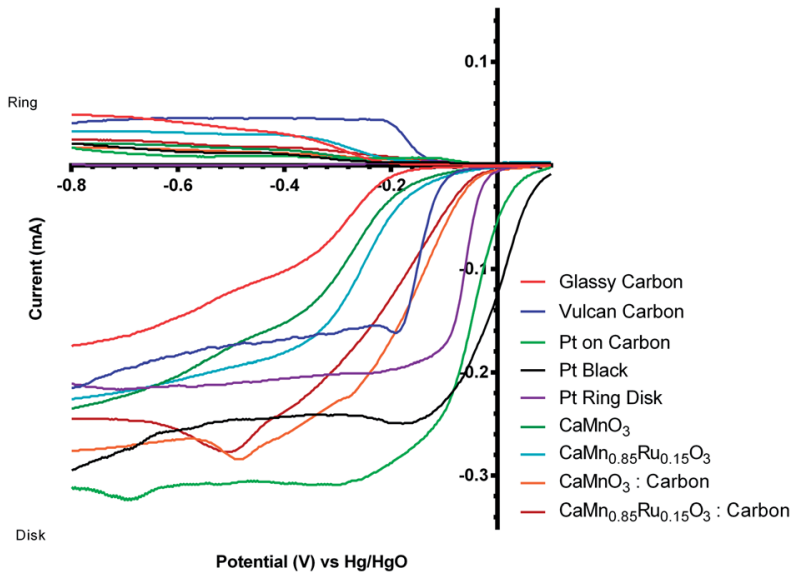

Fig. 12 Voltammograms for the $\mathrm{ORR}$ in $\mathrm{O}_{2}$-saturated aqueous $\mathrm{KOH}(1$ mol dm${ }^{-3}$ ) electrolyte for all "pre-degradation" catalysts (data from the $1^{\text {st }}$ voltammetric sweep). Scan rate $=20 \mathrm{mV} \mathrm{s}^{-1}$ and RRDE rotation rate $=200 \mathrm{rpm}$.

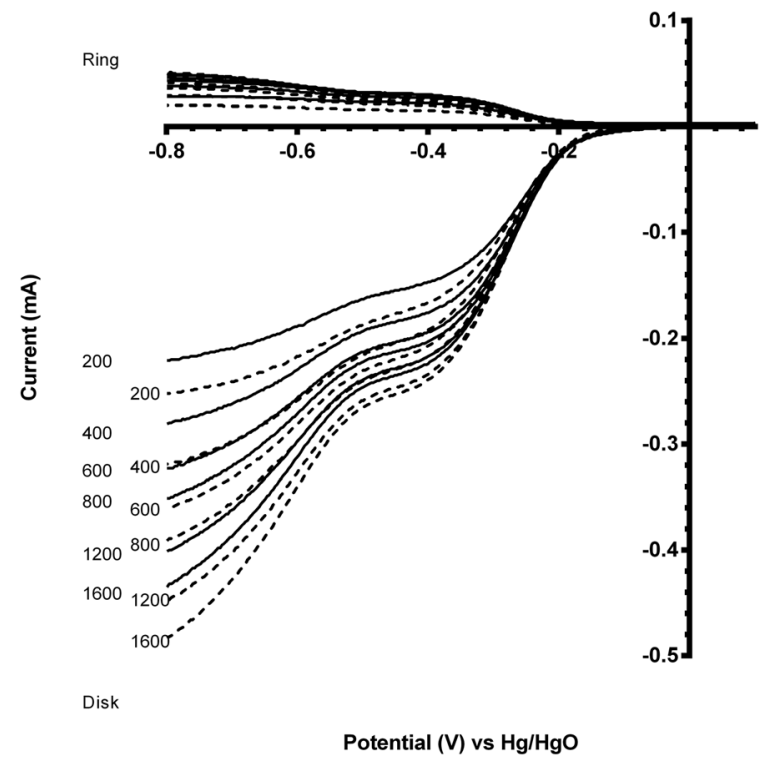

Fig. 13 Voltammograms for the $\mathrm{ORR}$ in $\mathrm{O}_{2}$-saturated aqueous $\mathrm{KOH}$ (1 $\mathrm{mol} \mathrm{dm}^{-3}$ ) electrolyte with the sol-gel synthesise $\mathrm{CaMn}_{1-x} \mathrm{Ru}_{x} \mathrm{O}_{3}(x=$ 0 (solid) and 0.15 (dashed)) catalysts that were mixed with Vulcan XC$72 \mathrm{R}$ and studied post-degradation (after 5 voltammetric sweeps). Scan rate $=5 \mathrm{mV} \mathrm{s}^{-1}$ with rotation rates of $200,400,600,800,1200$ and $1600 \mathrm{rpm}$.

separate unmixed Vulcan and inorganic catalysts (see Fig. 12 presenting the $1^{\text {st }}$ voltammetric sweep data) and the increase in the $n$ value towards the target $n=4$ (Table 3 ) on addition of the Vulcan.

However, the comparison of the two degraded perovskite/ carbon mixed catalysts (after 5 voltammetric sweeps) was surprising (Fig. 13). It was expected that the onset potential would follow the same trend as observed with the carbon-free catalysts, i.e. the Ru doped catalyst having a more positive onset potential. However when mixed with the Vulcan carbon, the Ru-containing and the Ru-free sol-gel catalysts had similar onset potentials, while the Ru-free catalyst had an $n$ value closer

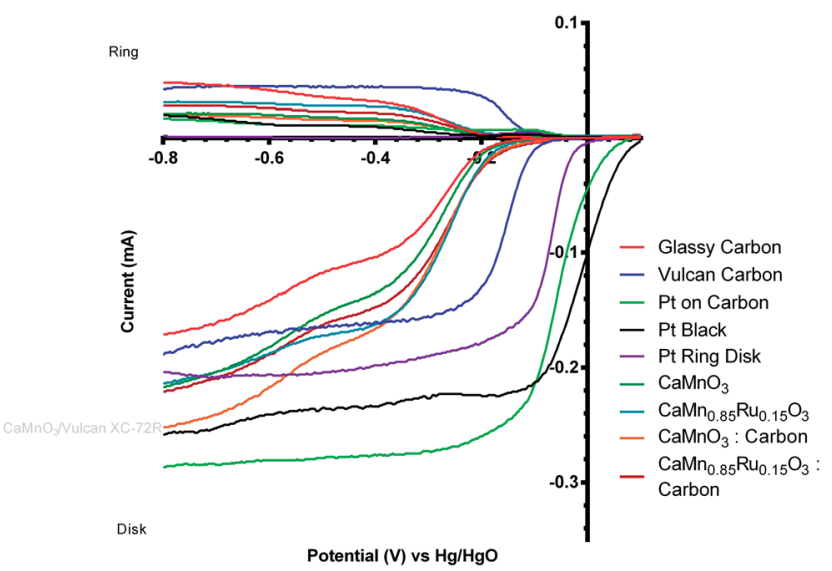

Fig. 14 Voltammograms for the ORR in $\mathrm{O}_{2}$-saturated aqueous $\mathrm{KOH}$ (1 mol $\mathrm{dm}^{-3}$ ) electrolyte for all "post-degradation" catalysts (data collected after 5 voltammetric sweeps). Scan rate $=20 \mathrm{mV} \mathrm{s}^{-1}$ and RRDE rotation rate $=200 \mathrm{rpm}$. 
to 4. In addition, when comparing the post-degradation performances of the $\mathrm{CaMnO}_{3} /$ Vulcan and the C-free CaMn $\mathrm{C}_{0.85}$ $\mathrm{Ru}_{0.15} \mathrm{O}_{3}$ catalysts, the onset potentials were surprisingly similar (Fig. 14). Catalyst degradation clearly represents a major interference towards the evaluation of the perovskite catalysts' electrochemical performance.

As stated earlier, Koutecky-Levich (K-L) analysis method can be used to determine the electron transfer of simple (e.g. well defined metallic) catalysts. The two controls used were a Pt-ring Pt-disk RRDE and a Pt-ring GC-disk RRDE both without application of any catalyst ink: it is known that the Pt disk should yield $n=4$ and the GC disk an $n$ value closer to 2. Eqn (10) gives the $\mathrm{K}-\mathrm{L}$ equation for a rotating ring disk electrode: ${ }^{26,27}$

$$
J_{\lim }=0.62 n F D^{\frac{2}{3}} \nu^{-\frac{1}{6}} \omega^{\frac{1}{2}} C^{\mathrm{o}} A
$$

where $J_{\text {lim }}=$ the limiting current on the disk, $n=$ number of electrons, $F=$ Faraday constant (96 $485 \mathrm{C} \mathrm{mol}^{-1}$ ), $D=$ the $\mathrm{O}_{2}$ diffusion coefficient (taken here as $=2.04 \times 10^{-5} \mathrm{~cm}^{2} \mathrm{~s}^{-1}$ ), $\nu=$ kinematic viscosity (taken here as $=0.01 \mathrm{~cm}^{2} \mathrm{~s}^{-1}$ ), $\omega=$ rotation rate $\left(\operatorname{rad~s}^{-1}\right), C^{\mathrm{o}}=$ bulk concentration of $\mathrm{O}_{2}$ (taken here as $=7.8$ $\times 10^{-7} \mathrm{~mol} \mathrm{~cm}^{-3}$ ), and $A=$ disk area (Pt-ring GC-disk RRDE $=$ $0.2475 \mathrm{~cm}^{2}$ and Pt-ring Pt-disk RRDE $=0.1642 \mathrm{~cm}^{2}$ ). Using a modified version of eqn (10) (eqn (11)), the $n$ values can be calculated from the gradient of the slopes in Fig. 15:

$$
n=\frac{1}{\text { slope }} / 0.62 F D^{\frac{2}{3}} \nu^{-\frac{1}{6}} C^{\mathrm{o}} A
$$

The gradients were $=20300$ and $24600 \mathrm{~A} \mathrm{rad}^{-1 / 2} \mathrm{~s}^{1 / 2}$ respectively for Pt and GC.

Table 5 shows the comparison between the $\mathrm{K}-\mathrm{L}$ and the ringvs. disk-current RRDE methods for all electrodes and catalysts studied. As can be seen, the $\mathrm{K}-\mathrm{L}$ analysis provides a reasonable agreement to the RRDE method for the Pt-ring

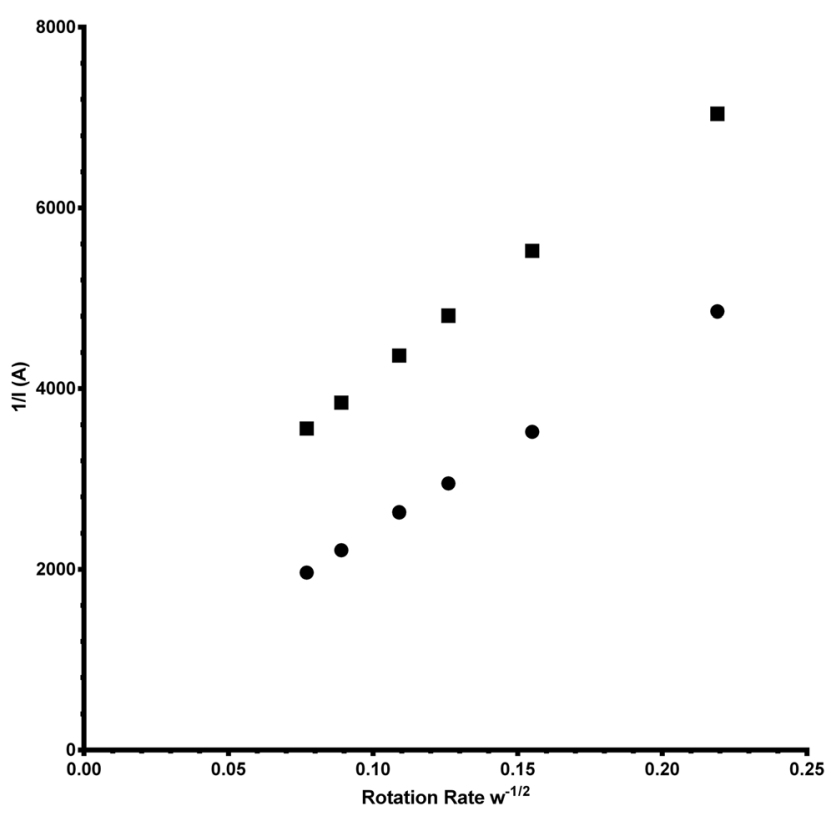

Fig. 15 Koutecky-Levich (K-L) plots for the Pt-ring Pt-disk (circles) and the Pt-ring GC-disk (squares) control RRDEs.
Table 5 Comparisons between $n$ values (number of electrons for ORR) calculated using the Koutecky-Levich $(\mathrm{K}-\mathrm{L})$ analysis and RRDE ring vs. disk current methods.

\begin{tabular}{lcc}
\hline RRDE & $n_{\mathrm{K}-\mathrm{L}}$ & $n_{\text {RRDE }}$ \\
\hline Pt-ring Pt disk & 4.04 & 3.95 \\
Pt-ring GC-disk & 2.19 & 2.57 \\
Vulcan XC-72R carbon black & 2.09 & 2.59 \\
Pt/C $(20 \% \mathrm{~m} / \mathrm{m} \mathrm{Pt})$ & 3.72 & 3.58 \\
Platinum black & 3.28 & 3.54 \\
$\mathrm{CaMnO}_{3}$ & 3.43 & 3.18 \\
$\mathrm{CaMn}_{0.85} \mathrm{Ru}_{0.15} \mathrm{O}_{3}$ & 3.22 & 3.04 \\
$\mathrm{CaMnO}_{3} / \mathrm{Vulcan} \mathrm{XC-72R}_{\mathrm{CaMn}_{0.85} \mathrm{Ru}_{0.15} \mathrm{O}_{3} / \text { Vulcan XC-72R }}^{3.96}$ & 3.27 \\
\hline
\end{tabular}

Pt(polycrystalline)-disk and Pt-ring GC-disk RRDE control electrodes. There is also reasonable agreement with the catalyst inks where the $\mathrm{K}-\mathrm{L}$ method tends to produce larger $n$ values than the RRDE method (with the exception of the Pt black and carbon-only experiments). These results highlight the usefulness of using the ring-current vs. disk-current (eqn (8)) method for elucidating the number of electrons used per $\mathrm{O}_{2}$ molecule for the ORR reaction: this is especially true for complex catalysts (such as the perovskite types discussed in this study), especially where there are no satisfactory validated methods for determining the appropriate specific surface areas of the (powdered) electrocatalyst to use in further analyses of the $\mathrm{K}-\mathrm{L}$ data.

\section{Conclusions}

$\mathrm{CaMn}_{1-x} \mathrm{Ru}_{x} \mathrm{O}_{3}(x=0$ and 0.15$)$ were compared to benchmark platinum and carbon fuel cell catalysts for use as cathode catalysts in alkaline fuel cells (including alkaline polymer electrolyte fuel cells). These tests were performed using rotating ring disk electrode (RRDE) oxygen reduction reaction (ORR) voltammetry in aqueous $\mathrm{KOH}\left(1 \mathrm{~mol} \mathrm{dm}^{-3}\right)$ solution. The method was validated by measurements with catalyst-ink-free RRDEs containing platinum and glassy carbon disks (which gave the expected ORR electron transfer numbers of $n=4$ and 2 respectively).

The benchmark catalysts exhibited higher onset potentials (due to their increased surface areas). The less than expected $n<$ $4 \mathrm{e}^{-}$observed for the inks containing the Pt-based catalysts was due to $(n \approx 2)$ interferences from the carbon supports and the glassy carbon disk of the RRDE.

The initial ( $1^{\text {st }}$ sweep data) measurements with the $\mathrm{CaMn}_{1-x}$ $\mathrm{Ru}_{x} \mathrm{O}_{3}$ catalysts (synthesised using the sol-gel method) yielded an increase in onset potentials compared to the glassy-carbon (GC) disk-only RRDE. With the further addition of Vulcan XC-72R to the $\mathrm{CaMn}_{1-x} \mathrm{Ru}_{x} \mathrm{O}_{3}$ catalysts, the onset potential further increased (more positive) due to the larger area of interface between the $\mathrm{CaMn}_{1-x} \mathrm{Ru}_{x} \mathrm{O}_{3}$ catalysts and the carbon "support". The trend in onset potentials ( $1^{\text {st }}$ sweep data) increased (from negative to more positive) in the order: $\mathrm{GC}$ disk control $<\mathrm{CaMnO}_{3}<\mathrm{CaMn}_{0.85}$ $\mathrm{Ru}_{0.15} \mathrm{O}_{3}<$ Vulcan XC-72R benchmark $<\mathrm{CaMn}_{0.85} \mathrm{Ru}_{0.15} \mathrm{O}_{3}+$ Vulcan $<\mathrm{CaMnO}_{3}+$ Vulcan $<$ Pt disk control $<$ Pt $/ \mathrm{C}$ (20\% mass Pt) benchmark $<$ Pt black benchmark. 
However further doping experiments are needed to stabilise these solid state catalysts as there is a severe reduction (negative shift) in the onset potential on further cycling after the $1^{\text {st }}$ sweep data. After 3-5 sweeps of degradation, the revised trend in onset potentials is changed to: $\mathrm{GC}$ disk control < $\mathrm{CaMnO}_{3}$, $\mathrm{CaMn}_{0.85} \mathrm{Ru}_{0.15} \mathrm{O}_{3}<\mathrm{CaMn}_{0.85} \mathrm{Ru}_{0.15} \mathrm{O}_{3}+$ Vulcan $<\mathrm{CaMnO}_{3}+$ Vulcan $<$ Vulcan XC-72R benchmark $<$ Pt disk control $<\mathrm{Pt} / \mathrm{C}$ benchmark $<$ Pt black benchmark. This decrease was due to the hypothesised degradation of the catalysts in the alkaline conditions with the presence of (electro-generated) peroxide.

Even though the trend for the onset potentials changed on degradation of the catalysts, the trend in ORR electron transfer numbers stayed the same for both the pre- and post-degraded $\mathrm{CaMn}_{1-x} \mathrm{Ru}_{x} \mathrm{O}_{3}$ catalysts. The observed trend in $n$ was: GC disk control < Vulcan XC-72R benchmark $<\mathrm{CaMn}_{0.85} \mathrm{Ru}_{0.15} \mathrm{O}_{3}<$ $\mathrm{CaMn}_{0.85} \mathrm{Ru}_{0.15} \mathrm{O}_{3} /$ Vulcan XC-72R $<\mathrm{CaMnO}_{3}<\mathrm{CaMnO}_{3} /$ Vulcan $\mathrm{XC}-72 \mathrm{R}<\mathrm{Pt}$ black benchmark $<\mathrm{Pt} / \mathrm{C}$ benchmark $<\mathrm{Pt}$ disk control.

\section{Acknowledgements}

The authors thank the UK's Engineering \& Physical Sciences Research Council (EPSRC) for funding (grants EP/I004882/1 and EP/G009929/2). The IviumStat bipotentiostat used was purchased using funding from EPSRC grant EP/H019480/1 (SuperGen Biological Fuel Cells consortium).

\section{Notes and references}

1 C. S. Song, Catal. Today, 2002, 77, 17.

2 H. Rogers, Oxf. Rev. Econ. Pol., 2011, 27, 117.

3 A. B. Stambouli and E. Traversa, Renewable Sustainable Energy Rev., 2002, 6, 433.

4 G. Merle, M. Wessling and K. Nijmeijer, J. Membr. Sci., 2011, $377,1$.

5 J. Tulloch and S. W. Donne, J. Power Sources, 2009, 188, 359. 6 A. Morozan, B. Jousselme and S. Palacin, Energy Environ. Sci., 2011, 4, 1238.
7 N. M. Markovic, T. J. Schmidt, V. Stamenkovic and P. N. Ross, Fuel Cells, 2001, 1, 105.

8 L. Qui, T. Ichikawa, A. Hirano, N. Imanishi and Y. Takeda, Solid State Ionics, 2003, 158, 55.

9 A. Tarancon, S. J. Skinner, R. J. Chater, F. HernandezRamirez and J. A. Kilner, J. Mater. Chem., 2007, 17, 3175.

10 P. Plonczak, M. Gazda, B. Kusz and P. Jasinski, J. Power Sources, 2008, 181, 1.

11 Y. Shimakawa, Inorg. Chem., 2008, 47, 8562.

12 S. J. Skinner, Int. J. Inorg. Mater., 2001, 3, 113.

13 R. H. E. Van Doorn and A. J. Burggraaf, Solid State Ionics, 2000, 128, 65.

14 G. J. K. Acres, J. Power Sources, 2001, 100, 60.

15 K. Xie, Y. Q. Zhang, G. Y. Meng and J. T. S. Irvine, J. Mater. Chem., 2011, 21, 195.

16 J. Molenda, K. Swierczek and W. Zajac, J. Power Sources, 2007, 173, 657.

17 K. Damen, M. van Troost, A. Faaij and W. Turkenburg, Prog. Energy Combust. Sci., 2006, 32, 215.

18 T. Kawada, K. Masuda, J. Suzuki, A. Kaimai, K. Kawamura, Y. Nigara, J. Mizusaki, H. Yugami, H. Arashi, N. Sakai and H. Yokokawa, Solid State Ionics, 1999, 121, 271.

19 S. B. Adler, Solid State Ionics, 1998, 111, 125.

20 T. Hyodo, M. Hayashi, S. Mitsutake, N. Miura and N. Yamazoe, J. Appl. Electrochem., 1997, 27, 745.

21 Y. Kiros, C. Myren, S. Schwartz, A. Sampathrajan and M. Ramanathan, Int. J. Hydrogen Energy, 1999, 24, 549.

22 A. L. Patternson, Phys. Rev., 1939, 56, 978.

23 W. S. Wang and A. V. Virkar, Sens. Actuators, B, 2004, 98, 282. 24 J. Sunarso, A. A. J. Torriero, W. Zhou, P. C. Howlett and M. Forsyth, J. Phys. Chem. C, 2012, 116, 5827.

25 B. Kumar, M. Llorente, J. Froehlich, T. Dang, A. Sathrum and C. P. Kubiak, Annu. Rev. Phys. Chem., 2012, 63, 541.

26 S. Treimer, A. Tang and D. C. Johnson, Electroanalysis, 2002, $14,165$.

27 C. H. Hamann, A. Hamnett and W. Vielstich, Electrochemistry, Wiley-VCH, Germany, 2nd edn, 2007, pp. 193-197. 